\title{
Gene promoter and exon DNA methylation changes in colon cancer development - mRNA expression and tumor mutation alterations
}

Béla Molnár ${ }^{1,2^{*}+}$, Orsolya Galamb ${ }^{1 \dagger}$, Bálint Péterfia², Barnabás Wichmann ${ }^{1}$, István Csabai ${ }^{3}$, András Bodor $^{3,4}$, Alexandra Kalmár ', Krisztina Andrea Szigeti², Barbara Kinga Barták², Zsófia Brigitta Nagy², Gábor Valcz', Árpád V. Patai ${ }^{2}$, Péter Igaz ${ }^{1,2}$ and Zsolt Tulassay ${ }^{1,2}$

\begin{abstract}
Background: DNA mutations occur randomly and sporadically in growth-related genes, mostly on cytosines. Demethylation of cytosines may lead to genetic instability through spontaneous deamination. Aims were whole genome methylation and targeted mutation analysis of colorectal cancer (CRC)-related genes and mRNA expression analysis of TP53 pathway genes.

Methods: Long interspersed nuclear element-1 (LINE-1) BS-PCR followed by pyrosequencing was performed for the estimation of global DNA metlyation levels along the colorectal normal-adenoma-carcinoma sequence. Methyl capture sequencing was done on 6 normal adjacent (NAT), 15 adenomatous (AD) and 9 CRC tissues. Overall quantitative methylation analysis, selection of top hyper/hypomethylated genes, methylation analysis on mutation regions and TP53 pathway gene promoters were performed. Mutations of 12 CRC-related genes (APC, BRAF, CTNNB1, EGFR, FBXW7, KRAS, NRAS, MSH6, PIK3CA, SMAD2, SMAD4, TP53) were evaluated. mRNA expression of TP53 pathway genes was also analyzed.

Results: According to the LINE-1 methylation results, overall hypomethylation was observed along the normaladenoma-carcinoma sequence. Within top50 differential methylated regions (DMRs), in AD-N comparison TP73, NGFR, PDGFRA genes were hypermethylated, FMN1, SLC16A7 genes were hypomethylated. In CRC-N comparison DKK2, SDC2, SOX1 genes showed hypermethylation, while ERBB4, CREB5, CNTN1 genes were hypomethylated. In certain mutation hot spot regions significant DNA methylation alterations were detected. The TP53 gene body was addressed by hypermethylation in adenomas. APC, TP53 and KRAS mutations were found in 30, 15, $21 \%$ of adenomas, and in 29,53,29\% of CRCs, respectively. mRNA expression changes were observed in several TP53 pathway genes showing promoter methylation alterations.
\end{abstract}

Conclusions: DNA methylation with consecutive phenotypic effect can be observed in a high number of promoter and gene body regions through CRC development.

Keywords: Colorectal cancer, Adenoma, DNA methylation, Mutation, Methyl capture sequencing, TP53 signaling pathway

\footnotetext{
* Correspondence: molnar.bela1@med.semmelweis-univ.hu

† Béla Molnár and Orsolya Galamb contributed equally to this work.

${ }^{1}$ Molecular Medicine Research Group, Hungarian Academy of Sciences,

Szentkirályi str 46, Budapest H-1088, Hungary

${ }^{2} 2$ nd Department of Internal Medicine, Semmelweis University, Szentkirályi

str 46, Budapest $\mathrm{H}-1088$, Hungary

Full list of author information is available at the end of the article
}

(C) The Author(s). 2018 Open Access This article is distributed under the terms of the Creative Commons Attribution 4.0 International License (http://creativecommons.org/licenses/by/4.0/), which permits unrestricted use, distribution, and

reproduction in any medium, provided you give appropriate credit to the original author(s) and the source, provide a link to the Creative Commons license, and indicate if changes were made. The Creative Commons Public Domain Dedication waiver (http://creativecommons.org/publicdomain/zero/1.0/) applies to the data made available in this article, unless otherwise stated. 


\section{Background}

Colorectal cancer (CRC) is a clinically important malignant disease due to its high incidence and mortality. According to the GLOBOCAN estimates with 1.4 million new cases and 694.000 deaths annually, CRC is the third most common cancer in the world, after lung and breast cancers [1].

The majority of sporadic CRCs develop according to the normal-adenoma-dysplasia-carcinoma sequence described by Fearon and Vogelstein [2]. The accumulation of genetic and epigenetic alterations in colonic epithelium leads to CRC through early and late precancerous adenoma stages in which promoter DNA methylation changes of certain tumor suppressor genes with consecutive mRNA expression changes are one of the earliest events, often prior to the appearance of mutations in well-known genes such as the adenomatosis polyposis coli gene $(A P C)[3]$.

Recently, comprehensive molecular characterization of several human cancers including CRC has been performed and the data integrated into The Cancer Genome Atlas (TCGA) database (https://cancergenome.nih.gov/). Integrative evaluation of genetic, epigenetic and gene expression data of hundreds of CRC and paired normal adjacent tissue (NAT) samples revealed that in addition to the known mutations, epigenetic changes (especially DNA methylation) also play a key role in establishing CRC subtypes with different prognostic and therapeutic phenotypes [4]. The majority (84\%) of CRCs were found to be non-hypermutated. Non-hypermutated cancers with distinct colonic or rectal location could be distinguished according to copy-number alteration, DNA methylation or gene expression profiles [4].

DNA methylation changes both in promoter and gene body regions contribute to cancer phenotype as they can affect the gene transcription in several ways [3, 5-7]. In addition to the earlier methods focusing on gene promoter methylation analysis, new technologies, such as BeadChip methylation arrays [4, 8-12], reduced representation bisulfite sequencing (RRBS) [13], whole genomic bisulfite sequencing (WGBS) and methyl capture sequencing (MethylCap-Seq) [7, 14] were applied to study DNA methylation profiles in CRC. While the majority of investigations included CRC and NAT tissues $[4,9,10,12,14]$, analysis of precancerous adenomas (AD) are represented in a small number of previous studies [8, 11] including a MethylCap-Seq study of WNT pathway genes we undertook [7]. We have also identified hypermethylated markers (mal, T-cell differentiation protein $(M A L)$, proline rich membrane anchor 1 (PRIMA1), prostaglandin D2 receptor (PTGDR) and secreted frizzled related protein 1 (SFRP1)) in CRC and adenoma using bisulfite sequencing [15] and determined a common ten-gene methylation signature in colorectal adenomas and CRC based on methylation qPCR arrays [16].

BeadChip $27 \mathrm{~K}$ and $450 \mathrm{~K}$ arrays and RRBS offer opportunities for analysis of DNA methylation at single nucleotide resolution mainly within $\mathrm{CpG}$ islands, however recently developed Epic BeadChip arrays - besides examination of $\mathrm{CpG}$ island methylation - allow more extensive study of CpG sites outside of CpG islands, as well. WGBS provides the most widespread whole methylome analysis at single nucleotide resolution, but it is not commonly used due to its high cost. MethylCap-seq is an alternative genome-wide methylation analysis technique to identify novel differentially methylated regions (DMRs) [17, 18]. It gives extensive information about both promoter and gene body methylation, though at lower resolution [18]. Unlike BeadChip arrays, it is suitable for investigation of mutation hot spot regions within the gene body. It is known that mutations can cause altered DNA methylation and DNA methylation changes also can lead to development of mutations $[19,20]$. The mutation rate is higher at methylated CpG sites than non-methylated ones [21, 22]. The change of 5-methylcytosine to thymine via spontaneous deamination [23, 24] 'which is less effectively repaired by the DNA repair machinery than the cytosine to uracil deamination reaction' $[22,23]$ can cause the increased mutability of cytosines within CpG sites.

The aim of this study was to analyze genome-wide tissue DNA methylation differences along the colorectal normal-adenoma-carcinoma sequence progression, including gene body methylation changes using MethylCap-seq. The second aim was to search for a potential relation between DNA methylation and mutation alterations for 12 CRC-associated genes. The possible effects of the genetic and epigenetic changes on neoplastic phenotype at transcriptome level were also examined.

\section{Methods \\ Estimation of global methylation levels using long interspersed nuclear element-1 (LINE-1) bisulfite sequencing}

After DNA isolation from 5 colorectal adenoma, 5 CRC and 10 normal $(\mathrm{N})$ colonic biopsy samples, bisulfite conversion of DNA samples was performed using EZ DNA Methylation-Direct Kit (Zymo Research). For quantification of methylation levels of the LINE-1 retrotransposable element, bisulfite-specific PCR (BS-PCR) was done and 146 bp long LINE-1 PCR products were sequenced on Pyromark Q24 system (Qiagen) using the Qiagen Q24 CpG LINE-1 Kit (Qiagen) according to the manufacturers' instruction.

\section{MethylCap-seq}

Global DNA methylation alterations were determined using MethylCap-seq data of 30 colonic tissue samples 
(15 AD, 9 CRC, 6 NAT) published previously by our research group [7]. In the previous study [7], only the DNA methylation changes of 160 WNT pathway genes and promoters were evaluated, while in this study whole methylome analysis was performed.

After informed consent of untreated patients, colonic biopsy samples were taken during routine endoscopic intervention. Using parallel formalin-fixed samples from the same site, histological diagnoses were established by experienced pathologists. Tissue samples from untreated CRC patients were also obtained from surgically removed colon or rectal tumors and from NAT that originated from the area farthest available from the tumor. The detailed patient specification has been described earlier [7]. The study was conducted according to the Helsinki declaration and approved by the local ethics committee and government authorities (Regional and Institutional Committee of Science and Research Ethics (TUKEB) Nr.: 69/2008, 202/2009 and 23,970/ 2011 Semmelweis University, Budapest, Hungary).

Genomic DNA was isolated using High Pure PCR Template Preparation Kit (Roche Applied Science) according to the manufacturer's instructions [16]. The capture of methylated DNA fragments and next generation sequencing were performed as previously described [7]. Briefly, after fragmentation of $3 \mu \mathrm{g}$ genomic DNA samples, the DNA fragments with methylated CpGs were selected using the Auto MethylCap kit (Diagenode). Purification of the methylated DNA fraction was carried out on QIAquick PCR purification columns (Qiagen). Library preparation was performed using the TruSeq ChIP Sample Preparation kit (Illumina) and clusters were generated using TruSeq SR Cluster Kit v3-cBot-HS (Illumina). Next generation sequencing of the methylated DNA fragments was performed on the HiScanSQ instrument using TruSeq SBS v3-HS reagents (Illumina,) according to the manufacturer's instructions. Bowtie2 software with default settings was used to map the 100 bp paired and 50 bp unpaired reads to the hg19 human genome reference assembly [25]. The aligned data were processed using the MEDIPS Bioconductor R package [26]. Methylation probabilities ( $\beta$-values hereafter) were calculated for $100 \mathrm{bp}$ long analysis windows (differentially methylated regions $=$ DMRs), with respect to genome-wide CpG density dependent Poisson distributions.

\section{Mutation analysis}

Using normal, benign and malignant colorectal tissue samples, mutation hot-spot regions of $12 \mathrm{CRC}$-associated genes $(A P C$, B-Raf proto-oncogene, serine/threonine kinase $(B R A F)$, catenin beta 1 (CTNNB1), epidermal growth factor receptor $(E G F R)$, F-box and WD repeat domain containing 7 (FBXW7), KRAS proto-oncogene, GTPase (KRAS), NRAS proto-oncogene, GTPase (NRAS), mutS homolog 6 (MSH6), phosphatidylinositol-4,5-bisphosphate 3-kinase catalytic subunit alpha (PIK3CA), SMAD family member 2 and 4 (SMAD2 and SMAD4), tumor protein 53 (TP53)) were amplified using a custom-made multiplex PCR panel previously designed by our research group [27]. Amplicon sequencing was carried out on a GS Junior instrument (Roche) using ligated and barcoded adaptors as described earlier [27]. Bead enrichment and sequencing were performed using GS Junior Titanium Sequencing Kit (Roche) according to the Sequencing Method Manual, GS FLX Titanium Series. For variant identification, Amplicon Variant Analyzer software (Roche) was applied.

\section{Promoter DNA methylation and mRNA expression analysis of TP53 signaling pathway genes}

The list of the TP53 pathway genes (in total 67 gene symbols) was constructed according to the KEGG pathway database. Promoters were defined as described earlier using Encode ChromHMM results [7]. Promoter DNA methylation was determined using methyl capture results of 30 colonic biopsy samples in a 100 base pair analysis window resolution and DMRs were identified between the diagnostic groups. In silico mRNA expression analysis for TP53 signaling pathway genes was performed using microarray data from colonic tissue samples (Affymetrix HGU133Plus2.0; GEO accession numbers: GSE37364 [28], GSE18105 [29], GSE4107 [30], GSE9348 [31], GSE22242 [32], GSE8671 [33]).

\section{Statistical analysis}

For MethylCap-seq DNA methylation data analysis, differences between diagnostic groups (9 CRC samples versus 6 NAT samples, $15 \mathrm{AD}$ samples versus 6 NAT samples) were characterized by $\Delta \beta$-values (the differences of the average $\beta$-values of each sample group). The top50 candidate DMRs were selected according to the highest absolute values of $\Delta \beta$-values. For estimation of global methylation levels using LINE-1 bisulfite sequencing, average methylation percentages of 3 analyzed $\mathrm{CpG}$ sites were calculated. For gene expression $\log \mathrm{FC}$ calculations, the differences between the averages of samples groups were compared. During statistical evaluation of DNA methylation and gene expression data, for paired comparisons of diagnostic groups, Student's t-test and False Discovery Rate (FDR) were applied as the Kolmogorov-Smirnov test resulted in normal distribution and the standard deviation of data were similar. Variance analysis was performed using the non-parametric Kruskal-Wallis test. A $p$-value of $<0.05$ was considered as significant.

\section{Results}

Global DNA methylation alterations of the colorectal normal-adenoma-carcinoma sequence

Genome-wide decreases in DNA methylation were observed for samples from the adenoma stage of colorectal 
carcinogenesis. Based on the LINE-1 bisulfite sequencing results, significant global DNA hypomethylation was detected both in CRC $(63 \pm 6.7 \% ; p=0.0302)$ and adenoma samples $(65 \pm 3.8 \% ; p=0.0093)$ compared to normal tissue $(73 \pm 1.4 \%)$. Variance analysis also revealed significantly lower DNA methylation level both in CRC and adenoma than in normal samples (Kruskal-Wallis test: $p$ $<0.00104$ ) (Fig. 1a). MethylCap-seq results showed that decreased DNA methylation appeared principally in 40$60 \%$ and $80-100 \%$ methylation percentage categories in adenoma and CRC samples compared to NAT controls (Fig. 1b).

\section{Top DMRs in CRC and adenoma samples identified by MethylCap-seq}

In CRC samples known CRC-associated genes including heparan sulfate-glucosamine 3-sulfotransferase 2 (HS3ST2), dickkopf WNT signaling pathway inhibitor 2 (DKK2), tissue factor pathway inhibitor 2 (TFPI2) and syndecan 2 $(S D C 2)$ occurred in the top50 significantly hypermethylated 100 base paired regions $(p<0.001)$, showing elevated promoter DNA methylation levels located within CpG islands. $\Delta \beta$-values representing methylation differences between CRC and NAT samples were in a range from 0.68 to 0.81 . More than one third of the top 50 hypermethylated DMRs align with weak $(9 \%)$ or active $(9 \%)$ promoters according to the Encode ChromHMM data. The majority of the top50 DMRs that were significantly hypomethylated in CRC compared to NAT samples $(p<0.001)$ could not be assigned to genes, gene promoters, and were located in intergenic regions. Similar to the hypermethylated DMRs, large differences were found for hypomethylated DMRs with $\Delta \beta$-values between -0.74 and -0.65 (Additional file 1 : Table S1A, B).

In the AD versus NAT comparison, $94 \%$ of the top 50 highly methylated DMRs were found in CpG islands including generally known CRC-associated DNA methylation markers like Fli-1 proto-oncogene, ETS transcription factor (FLI1), GATA binding protein 4 (GATA4) and nerve growth factor receptor (NGFR). The top50 significant $(p<0.0001)$ methylation alterations appeared to be more intensive in adenomas compared to NAT samples $(\Delta \beta$-values were between 0.86 and 0.79$)$. Considering Encode ChromHMM data, 38\% of top50 hypermethylated DMRs were found to be located in promoter regions, and $26 \%$ can function as active promoters. Similar to the results in CRC versus NAT comparison, almost all of the top50 DMRs showing significantly decreased DNA methylation in AD could not be annotated $(p<$ 0.0001 ) with stronger methylation differences than found in CRC versus NAT ( $\Delta \beta$-values between -0.90 and 0.74) (Additional file 1: Table S1C, D).

\section{DNA methylation alterations and expression of CRC-associated, frequently mutated genes}

The mutation frequencies of a panel consisting 12 CRC-associated genes in CRC and $\mathrm{AD}$ samples were measured in our previous multiplex PCR-based CRC mutation hot-spot sequencing study [27]. DNA methylation alterations were also detected in the mutation hot-spot regions of 12 analyzed CRC-associated genes that are frequently mutated, including TP53, APC, $K R A S, B R A F$ and $F B X W 7$. DNA methylation changes on 100 base pair long analysis windows located on mutation hot-spot regions of TP53, APC, KRAS, BRAF and $F B X W 7$ can be seen in Fig. 2. Evaluation of promoter methylation patterns of the 12 frequently mutated genes revealed several significant alterations including hypermethylation of the $A P C$ promoter in CRC and AD tissue specimens $(p<0.05 ; \Delta \beta=0.27-0.39)$ (Fig. 3a), hypermethylation of the TP53 promoter in $\operatorname{AD}(p<0.001 ; \Delta \beta=$ $0.40)$ and hypomethylation of CTNNB1 $(p<0.05 ; \Delta \beta$
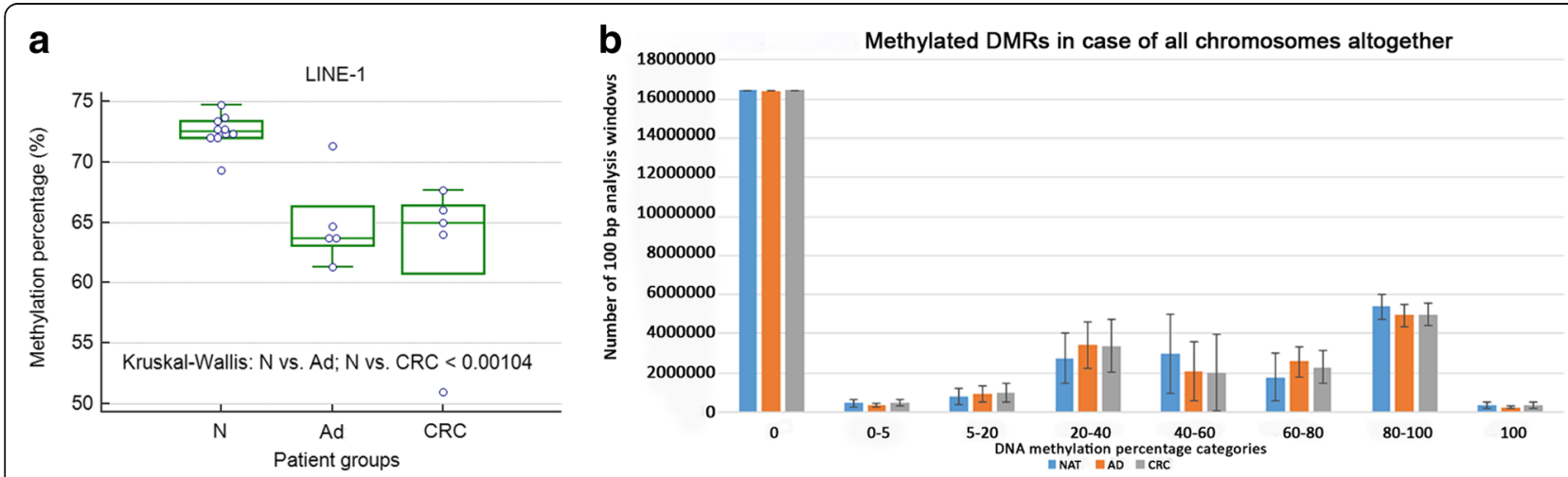

Fig. 1 Global DNA methylation alterations of the normal-adenoma-colorectal cancer sequence. a DNA methylation of LINE-1 (long interspersed nuclear element-1) in CRC, adenoma and normal tissue samples. $\mathrm{N}=$ normal, $\mathrm{Ad}=$ adenoma, $C R C=$ colorectal cancer; $\mathbf{b}$ Category distribution of global DNA methylation in CRC, adenoma and NAT samples analyzed by methyl capture sequencing. DNA methylation percentage categories are shown on the $X$ axis, while the numbers of 100 base pair analysis windows are represented on the $Y$ axis. NAT = normal adjacent tissue, $A D=$ adenoma, $\mathrm{CRC}=$ colorectal cancer 


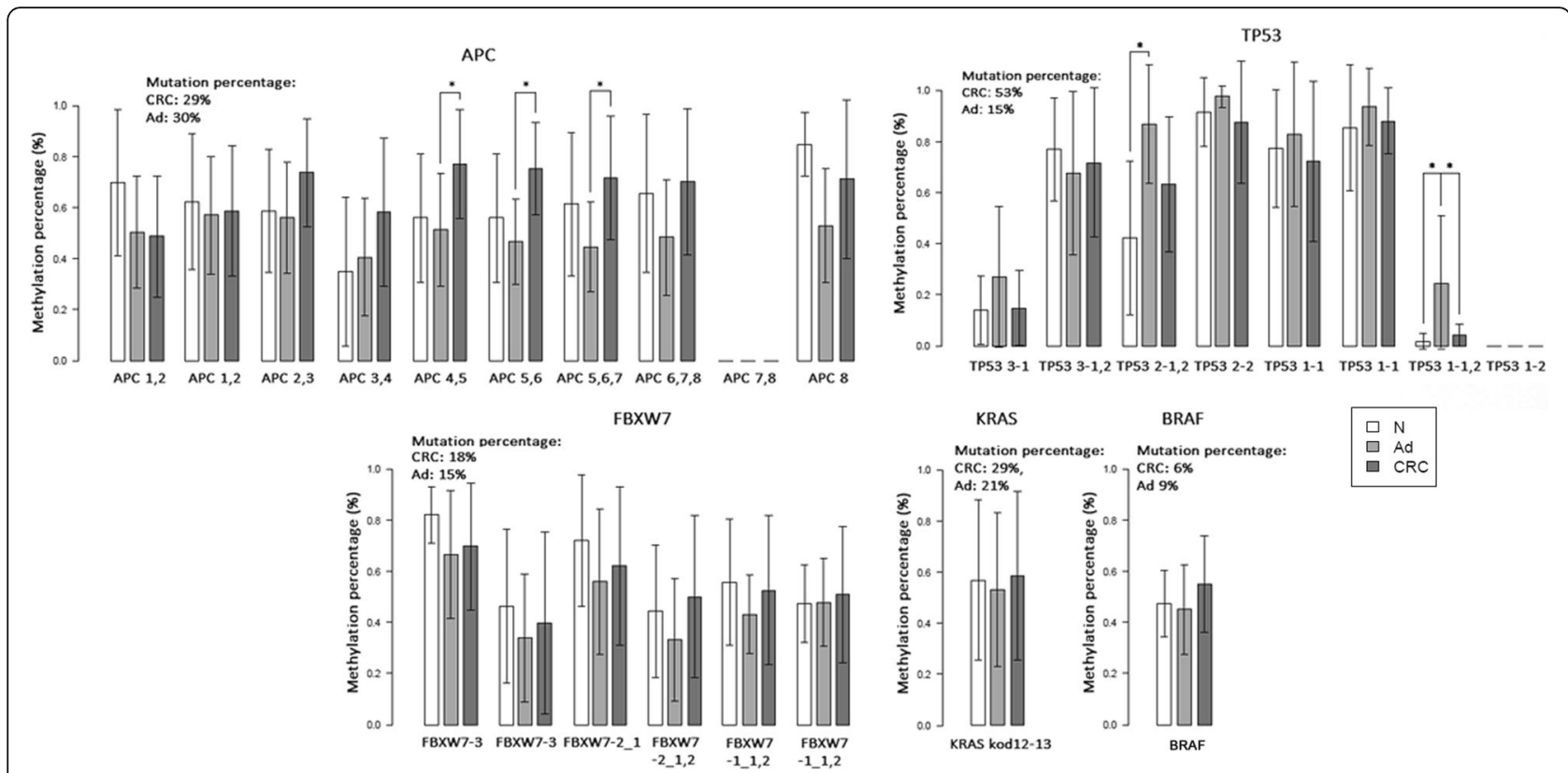

Fig. 2 DNA methylation alterations in mutation hot-spot regions of genes frequently mutated in CRC and adenoma. Methylation percentage values are shown in 100 base pair analysis regions located in mutation hot-spot areas of genes (TP53, APC, KRAS, BRAF and FBXW7) frequently mutated in CRC and adenoma tissue. The frequencies of mutations in CRC and adenoma samples detected in our previous multiplex PCR-based CRC mutation hot-spot sequencing study [27] are also represented. ${ }^{*} p<0.05, C R C=$ colorectal cancer, $\mathrm{Ad}=$ adenoma, $\mathrm{N}=$ normal adjacent tissue

between -0.30 and -0.45$)$ (Fig. 3a) and SMAD2 $(p=$ $0.024 ; \Delta \beta=-0.28)$ in CRC compared to NAT samples. $S M A D 4$ promoter region was found to be hypomethylated both in $\mathrm{AD}$ and CRC biopsy samples $(\mathrm{p}<0.05 ; \Delta \beta$ between -0.25 and -0.32 ). mRNA expression profiles of the 12 analyzed CRC-associated genes revealed that $A P C$ and CTNNB1 could be regulated by DNA methylation during the colorectal carcinogenesis as showing inverse relation between promoter DNA methylation and mRNA expression (Fig. 3b) .

\section{DNA methylation on TP53 signaling pathway gene promoters - Relation with gene expression results}

The TP53 pathway genes selected according to the KEGG pathway database were represented with 67 gene symbols. Promoters were defined as described earlier using Encode ChromHMM results [7]. In the CRC versus NAT comparison, $26.9 \%$ of TP53 pathway genes (18 from 67 genes) showed significant DNA methylation alterations in their promoter regions with at least a $10 \%$ methylation difference $(p<0.05, \Delta \beta \geq 0.1)$ (Table 1). In CRC samples hypermethylated DMRs were found in the promoter regions of 11 genes such as caspase 8 (CASP8), cyclin dependent kinase inhibitor $1 \mathrm{~A}$ and $2 \mathrm{~A}$ (CDKN1A and CDKN2A), insulin-like growth factor binding protein 3 (IGFBP3), sestrin 2 (SESN2) and tumor protein p73 (TP73), while seven TP53 pathway genes including G2 and S-phase expressed 1 (GTSE1) showed hypomethylation in their promoters. The box plots of the significant hyper-, and hypomethylated DMRs in TP53 pathway gene promoters showing the highest DNA methylation differences between CRC and NAT samples are represented on Fig. 4 and the box plots of all DMRs fulfilling the criteria can be seen in Additional file 2: Figure S1.

By applying the same criteria, significant promoter DNA methylation changes were observed in $37.3 \%$ of TP53 pathway genes (25/67) in AD compared to NAT samples $(\mathrm{p}<0.05, \Delta \beta \geq 0.1)$ (Table 1$)$. Fifteen TP53 pathway genes showed elevated promoter methylation in AD samples including CDKN2A, IGFBP3 and TP73, while hypomethylation was detected in the promoter regions of 10 genes such as GTSE1, damage specific DNA binding protein $2(D D B 2)$ and cyclin dependent kinase 1 (CDK1).

Using in silico expression analysis of microarray data from colonic biopsy samples (Affymetrix HGU133Plus2.0 GEO accession numbers: GSE37364 [28], GSE18105 [29], GSE4107 [30], GSE9348 [31], GSE22242 [32], GSE8671 [33]), an inverse relation between promoter DNA methylation alteration and mRNA expression (Table 2) was shown for a number of differentially methylated TP53 pathway genes including CDKN1A, CDKN2A, GTSE1, IGFBP3, SESN2 and SESN3 (Table 2).

\section{Discussion}

The accumulation of DNA methylation alterations accompanied by genetic changes such as mutations and 


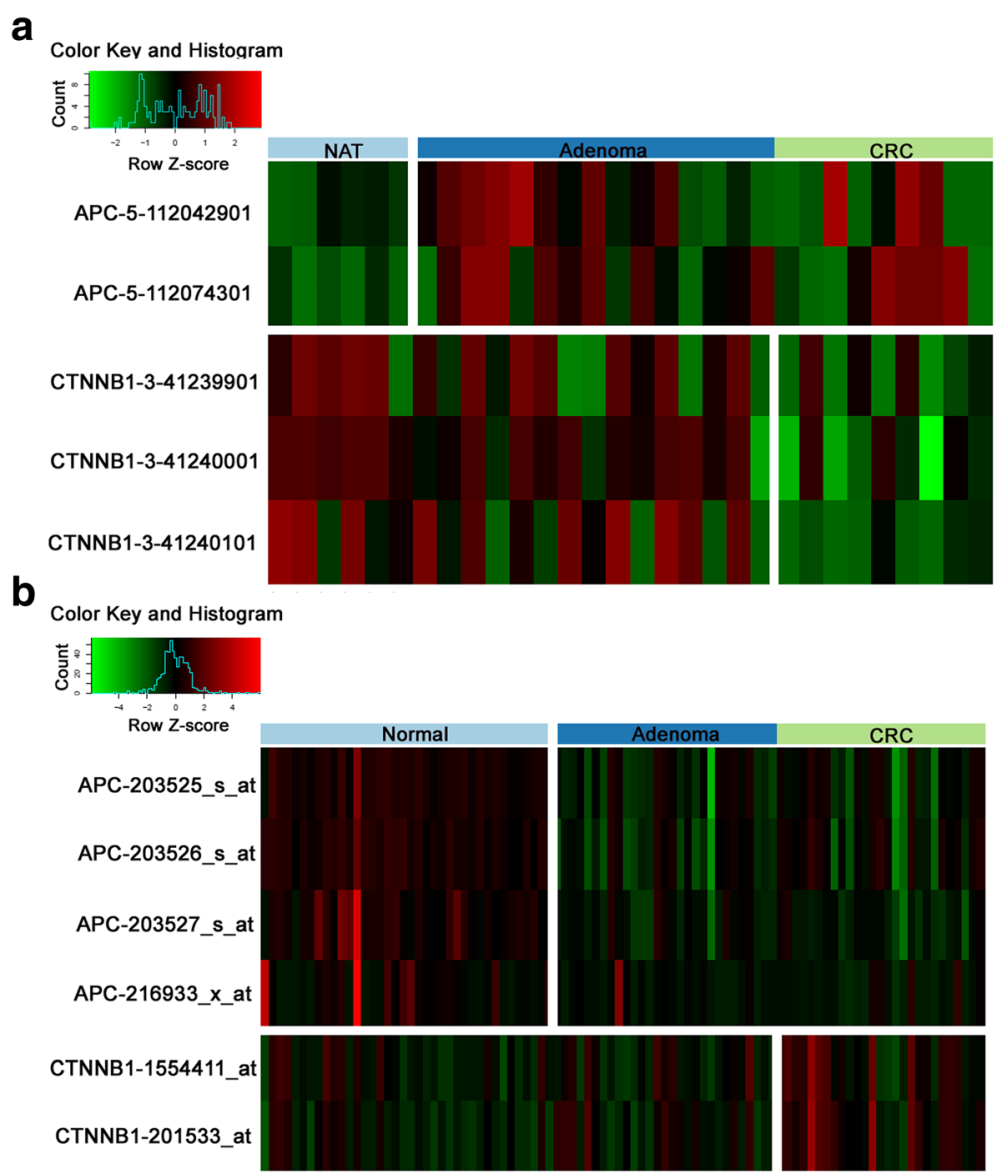

Fig. 3 Inverse promoter DNA methylation and mRNA expression alterations of APC and CTNNB1 genes in CRC and adenoma samples. a Significant DMRs in promoter regions of APC and CTNNB1 genes in CRC and adenoma samples $(p<0.05)$. Hypermethylation is marked with red, while hypomethylated DMRs are green. The names of the DMRs indicate the official gene symbol_number of the chromosome_start position of the DMR. CRC = colorectal cancer, NAT = normal adjacent tissue. $\mathbf{b}$ mRNA expression pattern of APC and CTNNB1 genes in CRC and adenoma (GSE37364 [28]). Overexpression is marked with red, while downregulated genes are green. CRC = colorectal cancer

deletions is known to contribute to the pathogenesis of various cancer types including CRC [3, 4]. Comprehensive DNA methylation changes found in precancerous adenoma stages can serve as early detection markers $[7,8,11$, 34]. In this study, global DNA methylation alterations were analyzed along the colorectal normal-adenoma-carcinoma sequence, and top differentially methylated genes/regions were identified using genome-wide MethylCap-seq analysis. The second aim of the study was to find out if there is a potential correlation between DNA methylational and mutational alterations for 12 CRC-associated genes. Furthermore, the possible effects of the genetic and epigenetic changes on TP53 signaling pathway genes at the transcriptome level were also examined.

Global hypomethylation was detected by LINE-1 bisulfite sequencing in CRC samples compared to normal tissue in line with previous data [35-37]. Although to a lower extent, global DNA hypomethylation could be detected as early as the AD stage. LINE-1 bisulfite sequencing was used for overall hypomethylation analysis due to its superior advance over MethylCap-seq, which predominantly targets genomic regions with high methylated CpGs density [14].

In this study, we identified 22 novel AD- and/or CRC-associated hypermethylated DMRs (approximately one fourth of top50 hypermethylated DMRs) which could be assigned to genes with previously undescribed methylation changes in cancers including CRC. These markers are principally involved in transcription regulation (e.g. BHLHE23, CUX2, HLX, MAFB, MKX, NKX11, and GSC2), transport processes (e.g. SLC24A2, GLRA3, LRRC38, SNAP91), and intracellular signaling (e.g. RGS20, GNAL, NRG3). Among the hypermethylated transcription factors, the expression of $\mathrm{H} 2.0$ like homeobox $(H L X)$ was found to be reduced in moderately differentiated CRCs [38]. Moreover, $H L X$ is also considered as a tumor suppressor in hepatocellular carcinoma [39]. The platelet derived growth factor receptor alpha 
Table 1 DNA methylation alterations in promoter regions of TP53 signaling pathway genes in CRC and AD tissues compared to NAT samples

\begin{tabular}{|c|c|c|c|c|c|c|}
\hline Gene symbol & Gene name & chr & start & stop & $\begin{array}{l}\Delta \beta \\
\text { (CRC-NAT) }\end{array}$ & $\begin{array}{l}\Delta \beta \\
(A D-N A T)\end{array}$ \\
\hline ATM & ATM serine/threonine kinase & 11 & 108092901 & 108093000 & & $0.22^{*}$ \\
\hline ATR & ATR serine/threonine kinase & 3 & 142298701 & 142298800 & $0.26^{*}$ & \\
\hline$B A X$ & BCL2 associated $X$, apoptosis regulator & 19 & 49457601 & 49457700 & & $-0.20^{*}$ \\
\hline \multirow[t]{3}{*}{$B B C 3$} & BCL2 binding component 3 & 19 & 47734901 & 47735000 & & $0.29^{*}$ \\
\hline & & & 47735001 & 47735100 & & $0.24^{*}$ \\
\hline & & & 47735601 & 47735700 & & $-0.17^{*}$ \\
\hline \multirow[t]{6}{*}{ CASP8 } & caspase 8 & 2 & 202098501 & 202098600 & & $0.31^{* *}$ \\
\hline & & & 202098601 & 202098700 & & $0.26^{*}$ \\
\hline & & & 202122001 & 202122100 & & $0.21^{*}$ \\
\hline & & & 202122101 & 202122200 & & $0.32^{*}$ \\
\hline & & & 202123101 & 202123200 & $0.27^{*}$ & \\
\hline & & & 202123201 & 202123300 & $0.43^{* * *}$ & \\
\hline \multirow[t]{3}{*}{ CCND3 } & cyclin D3 & 6 & 41908401 & 41908500 & & $-0.20^{*}$ \\
\hline & & & 42016801 & 42016900 & & $0.21^{*}$ \\
\hline & & & 42016901 & 42017000 & & $0.27^{*}$ \\
\hline CCNE1 & cyclin E1 & 19 & 30303701 & 30303800 & $0.51^{* *}$ & \\
\hline \multirow[t]{2}{*}{ CDK1 } & cyclin dependent kinase 1 & 10 & 62539101 & 62539200 & & $-0.25^{*}$ \\
\hline & & & 62539201 & 62539300 & & $-0.33^{* *}$ \\
\hline \multirow[t]{3}{*}{ CDK6 } & cyclin dependent kinase 6 & 7 & 92466601 & 92466700 & & $0.33^{* *}$ \\
\hline & & & 92466701 & 92466800 & & $0.29^{*}$ \\
\hline & & & 92466801 & 92466900 & & $0.26^{*}$ \\
\hline CDKNIA & cyclin dependent kinase inhibitor $1 \mathrm{~A}$ & 6 & 36644601 & 36644700 & $0.23^{*}$ & \\
\hline \multirow[t]{3}{*}{ CDKN2A } & cyclin dependent kinase inhibitor $2 \mathrm{~A}$ & 9 & 21975301 & 21975400 & $0.29^{*}$ & \\
\hline & & & 21993901 & 21994000 & & $0.25^{*}$ \\
\hline & & & 21994001 & 21994100 & & $0.37^{*}$ \\
\hline \multirow[t]{3}{*}{ CHEK1 } & checkpoint kinase 1 & 11 & 125496401 & 125496500 & & $0.23^{*}$ \\
\hline & & & 125496501 & 125496600 & & $0.42^{* *}$ \\
\hline & & & 125496601 & 125496700 & & $0.32^{*}$ \\
\hline \multirow[t]{3}{*}{ CYCS } & cytochrome c, somatic & 7 & 25164001 & 25164100 & & $0.32^{*}$ \\
\hline & & & 25164201 & 25164300 & & $0.33^{*}$ \\
\hline & & & 25165801 & 25165900 & $0.17^{*}$ & \\
\hline \multirow[t]{2}{*}{ DDB2 } & damage specific DNA binding protein 2 & 11 & 47237401 & 47237500 & & $-0.28^{*}$ \\
\hline & & & 47237501 & 47237600 & & $-0.29^{*}$ \\
\hline \multirow[t]{3}{*}{ El24 } & El24, autophagy associated transmembrane protein & 11 & 125438801 & 125438900 & $0.29^{*}$ & \\
\hline & & & 125438901 & 125439000 & $0.46^{* *}$ & \\
\hline & & & 125439001 & 125439100 & $0.36^{*}$ & \\
\hline \multirow[t]{4}{*}{ FAS } & Fas cell surface death receptor & 10 & 90751601 & 90751700 & $-0.43^{* * *}$ & \\
\hline & & & 90751701 & 90751800 & $-0.22^{*}$ & \\
\hline & & & 90751801 & 90751900 & $-0.45^{* * *}$ & $-0.27^{*}$ \\
\hline & & & 90751901 & 90752000 & $-0.26^{*}$ & \\
\hline GADD45A & growth arrest and DNA damage inducible alpha & 1 & 68150801 & 68150900 & & $0.30^{*}$ \\
\hline \multirow[t]{2}{*}{ GTSE1 } & G2 and S-phase expressed 1 & 22 & 46693501 & 46693600 & $-0.26^{*}$ & $-0.31^{* *}$ \\
\hline & & & 46693601 & 46693700 & & $-0.33^{* *}$ \\
\hline
\end{tabular}


Table 1 DNA methylation alterations in promoter regions of TP53 signaling pathway genes in CRC and AD tissues compared to NAT samples (Continued)

\begin{tabular}{|c|c|c|c|c|c|c|}
\hline Gene symbol & Gene name & chr & start & stop & $\begin{array}{l}\Delta \beta \\
(\text { CRC-NAT) }\end{array}$ & $\begin{array}{l}\Delta \beta \\
(A D-N A T)\end{array}$ \\
\hline IGF1 & insulin like growth factor 1 & 12 & 102871901 & 102872000 & $-0.26^{*}$ & $-0.23^{*}$ \\
\hline \multirow[t]{4}{*}{ IGFBP3 } & \multirow[t]{4}{*}{ insulin like growth factor binding protein 3} & \multirow[t]{4}{*}{7} & 45961101 & 45961200 & & $0.46^{*}$ \\
\hline & & & 45961401 & 45961500 & $0.54^{* *}$ & $0.73^{* * *}$ \\
\hline & & & 45961501 & 45961600 & $0.48^{*}$ & $0.60^{* * *}$ \\
\hline & & & 45961701 & 45961800 & & $0.42^{* *}$ \\
\hline MDM4 & MDM4, p53 regulator & 1 & 204486501 & 204486600 & & $0.14^{*}$ \\
\hline PTEN & phosphatase and tensin homolog & 10 & 89621101 & 896212200 & $-0.34^{*}$ & \\
\hline \multirow[t]{2}{*}{ RCHY1 } & \multirow[t]{2}{*}{ ring finger and $\mathrm{CHY}$ zinc finger domain containing 1} & \multirow[t]{2}{*}{4} & 76439201 & 76439300 & & $-0.23^{*}$ \\
\hline & & & 76440301 & 76440400 & & $-0.29^{*}$ \\
\hline RFWD2 & ring finger and WD repeat domain 2 & 1 & 176177801 & 176177900 & $-0.33^{*}$ & \\
\hline RRM2 & ribonucleotide reductase regulatory subunit M2 & 2 & 10261301 & 10261400 & $0.32^{*}$ & \\
\hline SERPINE1 & serpin family E member 1 & 7 & 100773001 & 100773100 & & $0.24^{*}$ \\
\hline \multirow[t]{2}{*}{ SESN1 } & \multirow[t]{2}{*}{ sestrin 1} & \multirow[t]{2}{*}{6} & 109331401 & 109331500 & & $0.27^{*}$ \\
\hline & & & 109416501 & 109416600 & & $0.11^{*}$ \\
\hline SESN2 & sestrin 2 & 1 & 28585601 & 28585700 & $0.24^{*}$ & \\
\hline SESN3 & sestrin 3 & 11 & 94965001 & 94965100 & $-0.24^{*}$ & \\
\hline \multirow[t]{2}{*}{ SFN } & \multirow[t]{2}{*}{ stratifin } & \multirow[t]{2}{*}{1} & 27189901 & 27190000 & & $-0.35^{*}$ \\
\hline & & & 27190301 & 27190400 & & $-0.34^{*}$ \\
\hline SHISA5 & shisa family member 5 & 3 & 48513701 & 48513701 & & $0.24^{*}$ \\
\hline \multirow[t]{2}{*}{ THBS1 } & \multirow[t]{2}{*}{ thrombospondin 1} & \multirow[t]{2}{*}{15} & 39871901 & 39872000 & $-0.27^{*}$ & \\
\hline & & & 39872801 & 39872900 & & $-0.22^{*}$ \\
\hline \multirow[t]{3}{*}{ TP73 } & \multirow[t]{3}{*}{ tumor protein p73 } & \multirow[t]{3}{*}{1} & 3567901 & 3567901 & $0.58^{* *}$ & $0.82^{* * *}$ \\
\hline & & & 3568001 & 3568001 & $0.53^{*}$ & $0.81^{* * *}$ \\
\hline & & & 3568101 & 3568101 & & $0.26^{*}$ \\
\hline TSC2 & TSC complex subunit 2 & 16 & 2097201 & 2097300 & & $-0.26^{*}$ \\
\hline
\end{tabular}

$p<0.05 * ; p<0.01 * * ; p<0.001 * * *$

(PDGFRA) was observed to be hypermethylated in $\mathrm{AD}$ compared to normal controls in our study. It was found to be overexpressed in CRC, but - in accordance with promoter hypermethylation detected in our MethylCap-seq study - it was down-regulated in adenomatous polyps [40]. Nevertheless, one fifth of hypermethylated and the majority of hypomethylated DMRs could not be associated with known genes, both in CRC versus NAT and AD versus NAT comparisons. The identified significant top50 methylation changes could be observed in a high proportion $(>80 \%)$ of the specimens within a sample group compared to the mutational alterations analyzed in this study.

On the basis of the methylation levels of the top50 hypomethylated and hypermethylated markers determined in this study, including the newly identified DMRs, the clear separation of CRC and NAT samples was also apparent for an independent sample set (Additional file 2: Figure S2). Furthermore, a partially overlapping set of samples also showed consistent DNA methylation profiles analyzed by MethylCap-seq and EpiTect Methyl qPCR methods (Additional file 2: Figure S3).

Approximately half of the top50 identified hypermethylated DMRs in CRC represent genes found to demonstrate elevated DNA methylation levels in different types of cancers $[14,16,34,41-60]$. Seven of the top50 markers (BNC1 [16], DKK2 [48-50], HS3ST2 [51], MIR124-3 [52], SDC2 [14, 34, 53, 54], TFPI2 [55, 56] and ZIC1 [57]) were previously described as methylated genes in CRC. Hypermethylation of basonuclin (BNC1) zinc finger protein, $S D C 2$ transmembrane heparin sulfate proteoglycan, and DKK2 dickkopf WNT signaling pathway inhibitor 2 genes were also reported in previous studies by our research group [16, 34]. Among the annotated AD versus NAT top50 hypermethylated DMRs, several markers were found to be hypermethylated in various cancers including FLI1 [58, 59], GATA4 [51] and NGFR [60]. These showed elevated methylation levels in CRC samples in other studies. 


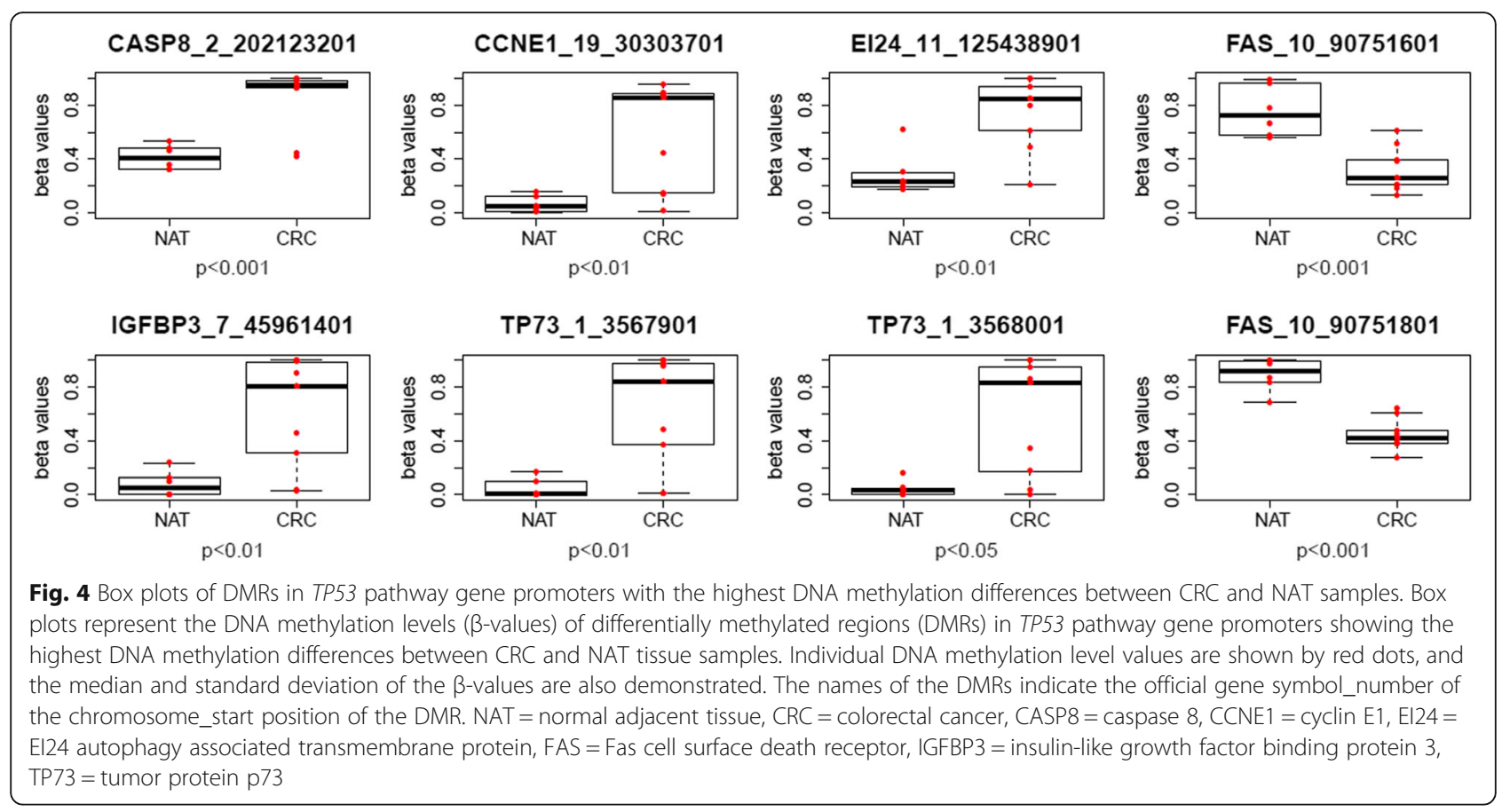

Table 2 TP53 signaling pathway genes showing inverse relation between promoter DNA methylation and mRNA expression

\begin{tabular}{|c|c|c|c|c|}
\hline $\begin{array}{l}\text { Gene } \\
\text { symbol }\end{array}$ & Gene name & $\begin{array}{l}\text { promoter DNA methylation in } \\
\text { our Metcap-Seq study* }\end{array}$ & $\begin{array}{l}\text { mRNA expression in tumor/ } \\
\text { adenoma versus normal } \\
\left(\log F C_{\min } \text { and } \log F C_{\max }\right)^{* *}\end{array}$ & Alterations in cancer/CRC/adenoma*** \\
\hline$B A X$ & $\begin{array}{l}\mathrm{BCL2} \text { associated } \mathrm{X} \text {, apoptosis } \\
\text { regulator }\end{array}$ & hypomethylated in adenoma & 0.36 and 1.09 & - downregulation in CRC [72] \\
\hline CDK1 & cyclin dependent kinase 1 & hypomethylated in adenoma & 0.42 and 2.12 & - overexpression in cancer [73] \\
\hline $\begin{array}{l}\text { CDKN1A } \\
(\mathrm{p} 21)\end{array}$ & $\begin{array}{l}\text { cyclin dependent kinase } \\
\text { inhibitor } 1 \mathrm{~A}\end{array}$ & hypermethylated in CRC & -2.16 and -0.67 & - loss of expression in CRC [74] \\
\hline $\begin{array}{l}\text { CDKN2A } \\
(\mathrm{p} 16)\end{array}$ & $\begin{array}{l}\text { cyclin dependent kinase } \\
\text { inhibitor } 2 \mathrm{~A}\end{array}$ & $\begin{array}{l}\text { hypermethylated in CRC } \\
\text { hypermethylated in adenoma }\end{array}$ & -0.81 & $\begin{array}{l}\text { - hypermethylated in CRC }[75,76] \text { and in } \\
\text { adenoma [76] }\end{array}$ \\
\hline CYCS & cytochrome c, somatic & $\begin{array}{l}\text { hypermethylated in CRC } \\
\text { hypermethylated in adenoma }\end{array}$ & $\begin{array}{l}-0.43 \text { and }-1.83 \\
-0.33 \text { and }-1.27\end{array}$ & $\begin{array}{l}\text { - loss of protein expression in CRC and in } \\
\text { adenoma [77] } \\
\text { - its downregulation correlates with apoptosis } \\
\text { resistance [77] }\end{array}$ \\
\hline DDB2 & $\begin{array}{l}\text { damage specific DNA binding } \\
\text { protein } 2\end{array}$ & hypomethylated in adenoma & 1.31 and 1.54 & $\begin{array}{l}\text { - suppresses tumorigenicity [78] } \\
\text { - reduces invasiveness of CRC [79] } \\
\text { - downregulated in high-grade CRC [79] }\end{array}$ \\
\hline GTSE1 & G2 and S phase expressed & $\begin{array}{l}\text { hypomethylated in CRC } \\
\text { hypomethylated in adenoma }\end{array}$ & 0.27 and 2.61 & - upregulation in several tumor types $[80,81]$ \\
\hline IGFBP3 & $\begin{array}{l}\text { insulin like growth factor } \\
\text { binding protein } 3\end{array}$ & $\begin{array}{l}\text { hypermethylated in CRC } \\
\text { hypermethylated in adenoma }\end{array}$ & -1.11 and -2.27 & $\begin{array}{l}\text { - hypermethylated in lung cancer [82] } \\
\text { - downregulation in esophageal carcinoma } \\
\text { [83] } \\
\text { - lower level is associated with increased } \\
\text { colon adenoma risk [84] }\end{array}$ \\
\hline SESN2 & sestrin 2 & hypermethylated in CRC & -1.86 and -0.72 & $\begin{array}{l}\text { - downregulation in tumors [85-87] } \\
\text { - predicts unfavorable CRC outcome [85] }\end{array}$ \\
\hline SESN3 & sestrin 3 & hypomethylated in CRC & 0.46 and 1.09 & $\begin{array}{l}\text { - involved in in vitro resistance to Irinotecan } \\
\text { [88] }\end{array}$ \\
\hline
\end{tabular}

${ }^{*} \Delta \beta$-values see in Table 1

**according to Affymetrix HGU133Plus2.0 microarray data (GEO accession numbers: GSE37364 [28], GSE18105 [29], GSE4107 [30], GSE9348 [31], GSE22242 [32], GSE8671 [33])

***according to previous literature data 
In this study, we present a comparative analysis between the promoter methylation and mRNA expression data of 12 genes frequently mutated during colorectal carcinogenesis and progression. The results revealed that DNA methylation can play a role in the regulation of $A P C$ and CTNNB1 expression in addition to and in parallel with the mutational changes. The above genes are members of the WNT signaling pathway investigated in details in our previous analysis [7]. Hypermethylation of the $A P C$ promoter $[7,50,61,62]$ and hypomethylation of the CTNNB1 promoter [7, 49] in AD and CRC samples have also been detected in other studies indicating that the DNA methylation alterations of frequently mutated canonical WNT pathway key genes can contribute to its constitutive activation in colorectal carcinogenesis from the premalignant adenoma stage.

Farkas et al. evaluated DNA methylation changes of genes frequently mutated in CRC using BeadChip450K technology, including 11 of the 12 genes analyzed in our study [49] and reported hypomethylation in CTNNB1 and SMAD2 promoters in CRC compared to NAT samples. Decreased promoter DNA methylation levels of these genes were also observed in our MethylCap-seq analysis together with methylation alterations of other genes such as SMAD4 and TP53 promoters during colorectal carcinogenesis.

In the current project, DNA methylation alterations were also detected in the mutation hot-spot regions of 12 analyzed $C R C$-associated frequently mutated genes including TP53, APC, KRAS, BRAF, and FBXW7. In accordance with the observation that $\mathrm{C}-\mathrm{T}$ transitions at $\mathrm{CpG}$ sites are the most prevalent mutations in TP53 gene in colon tumors [63], the high mutation rate and methylation changes at mutation hot spot regions of this gene could be detected in our study. DNA methylation can cause mutations in tumor suppressor genes such as TP53, as mutations occur 10-40 times more frequently on the basis of methylated cytosine than of unmethylated cytosine [19, 20]. The conversion of 5-methylcytosine to thymine via spontaneous deamination $[23,24]$ or by the APOBEC/ AID system [64] can lead to a high mutational burden of 5-methylcytosine. The 5-methylcytosine can be involved in increased mutability through other mechanisms. According to a recent report, elevated $\mathrm{C}$ to $\mathrm{G}$ transversion rate in cancer genomes can be associated with 5-hydroxymethylcytosines derived by the oxidation of 5 -methylcytosine catalyzed by TET proteins [65].

Hypomethylation was also detected in addition to the elevated methylation levels on certain mutation hot-spots. This is only seemingly contradictory to previous data indicating that the mutation rate is higher on methylated CpG sites than on unmethylated ones [21], as the relative hypomethylation (from high level to intermediate level) and not the absolute loss of DNA methylation was observed on certain mutation hot-spots in our study. It is in conjunction with the results of a recent work describing that among the methylated $\mathrm{CpG}$ sites, the rate of mutations (or SNP density) was found to be increased on less methylated CpG sites (20-60\%) as compared to high-intermediately and highly methylated CpGs $(60-80 \%$; > 80\%) [21, 66]. Cancer-associated overall hypomethylation of the genome including heterochromatic DNA repeats, retrotransposons, and endogenous retroviral elements also contribute to genome instability [20].

In our analysis, DMRs could be identified on all chromosomes with the relatively largest number of aligned sequence reads on chromosome 17, similar to the MethylCap-seq study performed by Simmer et al. [14]. Next, DNA methylation alterations of TP53 (encoded on chr 17) signaling pathway genes were also investigated. TP53 pathway deregulation frequently occurs through the mutations or deletion of TP53 itself [67]. Outside the mutations of the TP53 gene, this pathway is rarely hit by any other mutations/polymorphisms [68-70]. Other mechanisms, such as epigenetic regulation including DNA methylation changes of TP53 pathway genes, also contribute to attenuating the pathway and participate in cancer development [67], and TP53 itself is also thought to regulate cancer-associated genes showing altered methylation patterns [71]. Accordingly, our MethylCap-Seq analysis revealed significant promoter DNA methylation changes in approximately one third of TP53 signaling pathway genes in CRC. Moreover, an even greater proportion of TP53 pathway gene promoters (around 40\%) showed altered DNA methylation in AD samples compared to NAT controls. The alterations of the identified TP53 pathway genes with inverse promoter DNA methylation and mRNA expression differences (Table 2) were found to be associated with tumorigenesis in different cancer types including CRC [72-88]. Among these markers, in addition to the down-regulation of well known p16 $(C D K N 2 A)$ [75, 76] and p21 (CDKN1A) [74] cyclin dependent kinase inhibitors, BCL2 associated X, apoptosis regulator $(B A X)$ [72], SESN2 [85-87], IGFBP3 [84] and cytochrome c, somatic (CYCS) [77] are also thought to exert tumor suppressor functions. Diminished or loss of CYCS protein expression in AD and CRC tissue was found to be correlated with apoptosis resistance [77]. DDB2 damage specific DNA binding protein, which was described to suppress the tumorigenicity in case of ovarian cancer [78] and reduces CRC invasiveness [79], showed promoter hypomethylation and overexpression in $\mathrm{AD}$ samples in our study, suggesting its contribution to the inhibition of uncontrolled expansion in the adenoma stage. 


\section{Conclusions}

Using genome-wide DNA methylation analysis, we identified novel aberrant methylation profiles of genes including HLX, CUX2, MKX, NRG3 and PDGFRA associated with the colorectal adenoma-carcinoma sequence progression. In addition to the genetic changes, DNA methylation alterations were also shown in the mutation hot-spot regions of 12 analyzed, CRC-associated, frequently mutated genes including, TP53, APC, KRAS, BRAF, and FBXW7. Global hypomethylation - which might be linked to genetic instability - could be detected as early as the adenoma stage.

Our study also revealed that promoter DNA methylation changes influence the mRNA expression level in the case of a significant part of the TP53 pathway genes. Thus epigenetic alterations can also contribute to a whole pathway-related effect on DNA repair and apoptosis in addition to single gene (e.g. TP53) mutations.

In summary, the methyl-capture sequencing technique yielded reproducible, clinically relevant results on the whole genome level which are related to cancer phenotype development through mRNA expression changes and to the cancer genotype through the link of mutation formation.

\section{Additional files}

Additional file 1: Table S1A. Top50 hypermethylated DMRs in CRC versus NAT comparison. Table S1B. Top50 hypomethylated DMRs in CRC versus NAT comparison. Table S1C. Top50 hypermethylated DMRs in adenoma tissue compared to NAT samples. Table S1D. Top50 hypomethylated DMRs in adenoma tissue compared to NAT samples. (DOC $253 \mathrm{~kb}$ )

Additional file 2: Figure S1. Box plots of significant DMRs in TP53 pathway gene promoters between CRC and NAT samples. Figure S2. DNA methylation pattern of top50 hypermethylated DMRs on an independent set of samples. Figure S3. DNA methylation profiles of the overlapping regions on methyl capture sequencing and EpiTect array results. (DOC 902 kb)

\section{Abbreviations}

AD: Adenoma; AID: Activation-induced cytidine deaminase; APC: Adenomatosis polyposis coli; APOBEC: Apolipoprotein B mRNA editing enzyme catalytic subunit; BAX: BCL2 associated $X$, apoptosis regulator; BHLHE23: Basic helix-loop-helix family member e23; BNC1: Basonuclin; BRAF: B-Raf proto-oncogene, serine/threonine kinase; BS-PCR: Bisulfitespecific polymerase chain reaction; CASP8: Caspase 8; CDK1: Cyclin dependent kinase 1; CDKN1A and CDKN2A: Cyclin dependent kinase inhibitor 1A and 2A; CNTN1: Contactin 1; CRC: Colorectal cancer; CREB5: CAMP responsive element binding protein 5; CTNNB1: Catenin beta 1; CUX2: Cut like homeobox 2; CYCS: Cytochrome c, somatic; DDB2: Damage specific DNA binding protein 2; DKK2: Dickkopf WNT signaling pathway inhibitor 2; DMR: Differentially methylated regions; EGFR: Epidermal growth factor receptor; ERBB4: Erb-b2 receptor tyrosine kinase 4; FBXW7: F-box and WD repeat domain containing 7; FDR: False Discovery Rate; FLI1: Fli-1 protooncogene, ETS transcription factor; FMN1: Formin 1; GATA4: GATA binding protein 4; GEO: Gene Expression Omnibus database; GLRA3: Glycine receptor alpha 3; GNAL: G protein subunit alpha L; GSC2: Goosecoid homeobox 2; GTSE1: G2 and S-phase expressed 1; HLX: H2.0 like homeobox; HS3ST2: Heparan sulfate-glucosamine 3-sulfotransferase 2; IGFBP3: Insulin-like growth factor binding protein 3; KRAS: KRAS proto-oncogene, GTPase; LINE1: Long interspersed nuclear element-1; LRRC38: Leucine rich repeat
}

containing 38; MAFB: MAF bZIP transcription factor B; MAL: Mal, T-cell differentiation protein; MethylCap-Seq: Methyl capture sequencing; MIR1243: MicroRNA 124-3; MKX: Mohawk homeobox; MSH6: MutS homolog 6; N: Normal tissue; NAT: Normal adjacent tissue; NGFR: Nerve growth factor receptor; NKX1-1: NK1 homeobox 1; NRAS: NRAS proto-oncogene, GTPase; NRG3: Neuregulin 3; PDGFRA: Platelet derived growth factor receptor alpha; PIK3CA: Phosphatidylinositol-4,5-bisphosphate 3-kinase catalytic subunit alpha; PRIMA1: Proline rich membrane anchor 1; PTGDR: Prostaglandin D2 receptor; RGS20: Regulator of G protein signaling 2; RRBS: Reduced representation bisulfite sequencing; SDC2: Syndecan 2; SESN2: Sestrin 2; SFRP1: Secreted frizzled related protein 1; SLC16A7: Solute carrier family 16 member 7; SLC24A2: Solute carrier family 24 member 2; SMAD2 and SMAD4: SMAD family member 2 and 4; SNAP91: Synaptosome associated protein 91; SOX1: SRY-box 1; TCGA: The Cancer Genome Atlas; TET: Tet methylcytosine dioxygenase; TFPI2: Tissue factor pathway inhibitor 2; TP53: Tumor protein p53; TP73: Tumor protein p73; WGBS: Whole genomic bisulfite sequencing; ZIC1: Zic family member 1

\section{Acknowledgements}

We thank hereby the help of Theo deVos PhD, Nha Le MD and Pál Vágvölgyi for their careful language assistance. The results shown here are in part based upon data generated by the TCGA Research Network: http://cancergenome.nih.gov/.

Data of the present manuscript was presented at the following conferences: 1. Galamb O, Wichmann B, Péterfia B, Kalmár A, Csabai I, Bodor A, Ribli D, Barták BK, Tóth K, Tulassay Z, Molnár B. Whole methylome analysis of colorectal tissue samples using methyl capture sequencing revealed epigenetic alterations of frequently mutated genes during normal-adenomacarcinoma sequence progression. 23rd United European Gastroenterology Week (Barcelona, Spain October 24-28, 2015).

2. Molnár B, Péterfia B, Wichmann B, Patai Á, Galamb O, Kalmár A, Tulassay Z. Whole genome sequencing in colorectal tumors: DNA methylation alterations of colorectal tumor mutation and hot spot genes (APC, P53, Bcatenin, KRAS). [Teljes genom methylációs szekvenálás vastagbél daganatokban: a vastagbél daganat mutációs gének és forrópontok (APC, P53, Bcatenin, KRAS) DNS methylációs megelőző elváltozásai]. Central Eur J Gastroenterol Hepatol. 2016;2 Suppl 1:105-6. (Hungarian Society of Gastroenterology 58th Annual Meeting, Siófok, Hungary, June 4-7, 2016).

3. Molnar B, Galamb O, Peterfia B, Wichmann B, Kalmar A, Nagy Á, Szigeti K, Márkus $E$, Tulassay Z. DNA methylation changes precede and contribute to mutational changes in colorectal adenoma and cancer development through genomic instability. Central Eur J Gastroenterol Hepatol. 2017;3 Suppl 1:110-1. (Hungarian Society of Gastroenterology 59th Annual Meeting, Siófok, Hungary, June 10-13, 2017).

4. Molnar B, Galamb O, Peterfia B, Wichmann B, Kalmar A, Nagy ZB, Bartak BK, Szigeti K, Markus E, Tulassay Z. DNA methylation changes precede and contribute to sporadic mutations in colorectal adenoma and cancer development through induced genomic instability. 25th United European Gastroenterology Week (Barcelona, Spain, October 28-November 1, 2017).

\section{Funding}

This study was supported by the National Research, Development and Innovation Office (KMR-12-1-2012-0216 and NVKP_16-1-2016-0004 grants), the Novo Nordisk Foundation Interdisciplinary Synergy Programme Grant no. NNF15OC0016584 and by the Hungarian Scientific Research Fund (OTKA-K111743 grant). The funding bodies had no role in the design of the study and collection, analysis, and interpretation of data and in writing the manuscript.

\section{Availability of data and materials}

Additional data and materials may be obtained from the corresponding author on reasonable request.

\section{Authors' contributions}

BM, OG, BP, ÁVP designed the study; BM, ÁVP, ZT collected the samples; OG, ÁVP, AK, GV contributed to the collection of clinical data collection and histological analysis of the samples; OG, BP, AK, KASZ, BKB an ZBN performed the experiments; BM, OG, BW, ICS, AB analyzed the experimental data; BM, ICS, ZT, IP contributed to the design and critical review of the manuscript, obtained fundings. All authors were involved in writing the paper, made a critical revision of the manuscript for important intellectual content and had final approval of the submitted and published versions. 


\section{Ethics approval and consent to participate}

The study was conducted according to the Helsinki declaration and approved by the local ethics committee and government authorities (Regional and Institutional Committee of Science and Research Ethics (TUKEB) Nr.: 69/2008, 202/2009 and 23,970/2011 Semmelweis University, Budapest, Hungary). Al routine colonic biopsy samples from the patients were taken after written informed consent and ethical permission was obtained for participation in the study.

\section{Consent for publication}

Not applicable.

\section{Competing interests}

The authors declare that they have no competing interests.

\section{Publisher's Note}

Springer Nature remains neutral with regard to jurisdictional claims in published maps and institutional affiliations.

\section{Author details}

${ }^{1}$ Molecular Medicine Research Group, Hungarian Academy of Sciences, Szentkirályi str 46, Budapest H-1088, Hungary. ${ }^{2}$ 2nd Department of Internal Medicine, Semmelweis University, Szentkirályi str 46, Budapest H-1088, Hungary. ${ }^{3}$ Department of Physics of Complex Systems, ELTE Eötvös Loránd University, Pázmány Péter sétány 1/A, Budapest H-1117, Hungary. ${ }^{4}$ Institute of Mathematics and Informatics, Faculty of Sciences, University of Pécs, Ifjúság útja 6, Pécs H-7624, Hungary.

Received: 15 November 2017 Accepted: 18 June 2018

Published online: 27 June 2018

\section{References}

1. Ferlay J, Soerjomataram I, Dikshit R, Eser S, Mathers C, Rebelo M, Parkin DM, Forman D, Bray F. Cancer incidence and mortality worldwide: sources, methods and major patterns in GLOBOCAN 2012. Int J Cancer. 2015;136: E359-86.

2. Vogelstein B, Fearon ER, Hamilton SR, Kern SE, Preisinger AC, Leppert M, Nakamura Y, White R, Smits AM, Bos JL. Genetic alterations during colorectal-tumor development. N Engl J Med. 1988;319:525-32.

3. Lao W, Grady WM. Epigenetics and colorectal cancer. Nat Rev Gastroenterol Hepatol. 2011;8:686-700

4. Network CGA. Comprehensive molecular characterization of human colon and rectal cancer. Nature. 2012;487:330-7.

5. Costello JF, Frühwald MC, Smiraglia DJ, Rush L, Robertson GP, Gao X, Wright FA, Feramisco JD, Peltomäki P, Lang JC, et al. Aberrant CpG-island methylation has non-random and tumour-type-specific patterns. Nat Genet. 2000;24:132-8

6. Jones PA. Functions of DNA methylation: islands, start sites, gene bodies and beyond. Nat Rev Genet. 2012;13:484-92.

7. Galamb O, Kalmár A, Péterfia B, Csabai I, Bodor A, Ribli D, Krenács T, Patai ÁV, Wichmann B, Barták BK, et al. Aberrant DNA methylation of WNT pathway genes in the development and progression of CIMP-negative colorectal cancer. Epigenetics. 2016;11:588-602.

8. Beggs AD, Jones A, El-Bahrawy M, Abulafi M, Hodgson SV, Tomlinson IP. Whole-genome methylation analysis of benign and malignant colorectal tumours. J Pathol. 2013;229:697-704.

9. Hinoue $T$, Weisenberger DJ, Lange CP, Shen $H$, Byun HM, Van Den Berg D, Malik S, Pan F, Noushmehr H, van Dijk CM, et al. Genome-scale analysis of aberrant DNA methylation in colorectal cancer. Genome Res. 2012;22:271-82

10. Kibriya MG, Raza M, Jasmine F, Roy S, Paul-Brutus R, Rahaman R, Dodsworth C, Rakibuz-Zaman M, Kamal M, Ahsan H. A genome-wide DNA methylation study in colorectal carcinoma. BMC Med Genet. 2011;4:50.

11. Luo Y, Wong CJ, Kaz AM, Dzieciatkowski S, Carter KT, Morris SM, Wang J, Willis JE, Makar KW, Ulrich CM, et al. Differences in DNA methylation signatures reveal multiple pathways of progression from adenoma to colorectal cancer. Gastroenterology. 2014;147:418-29. e8

12. Naumov VA, Generozov EV, Zaharjevskaya NB, Matushkina DS, Larin AK, Chernyshov SV, Alekseev MV, Shelygin YA, Govorun VM. Genome-scale analysis of DNA methylation in colorectal cancer using Infinium HumanMethylation450 BeadChips. Epigenetics. 2013;8:921-34.
13. Hanley MP, Hahn MA, Li AX, Wu X, Lin J, Wang J, Choi AH, Ouyang Z, Fong Y, Pfeifer GP, et al. Genome-wide DNA methylation profiling reveals cancer-associated changes within early colonic neoplasia. Oncogene. 2017:36:5035-44.

14. Simmer $F$, Brinkman AB, Assenov $Y$, Matarese F, Kaan A, Sabatino L, Villanueva A, Huertas D, Esteller M, Lengauer $T$, et al. Comparative genome-wide DNA methylation analysis of colorectal tumor and matched normal tissues. Epigenetics. 2012;7:1355-67.

15. Kalmár A, Péterfia B, Hollósi P, Galamb O, Spisák S, Wichmann B, Bodor A, Tóth K, Patai ÁV, Valcz G, et al. DNA hypermethylation and decreased mRNA expression of MAL, PRIMA1, PTGDR and SFRP1 in colorectal adenoma and cancer. BMC Cancer. 2015;15:736.

16. Patai ÁV, Valcz G, Hollósi P, Kalmár A, Péterfia B, Patai Á, Wichmann B, Spisák S, Barták BK, Leiszter K, et al. Comprehensive DNA methylation analysis reveals a common ten-gene methylation signature in colorectal adenomas and carcinomas. PLoS One. 2015;10:e0133836.

17. Zhao Y, Sun J, Zhang H, Guo S, Gu J, Wang W, Tang N, Zhou X, Yu J. Highfrequency aberrantly methylated targets in pancreatic adenocarcinoma identified via global DNA methylation analysis using methylCap-seq. Clin Epigenetics. 2014;6:18.

18. De Meyer T, Bady P, Trooskens G, Kurscheid S, Bloch J, Kros JM, Hainfellner JA, Stupp R, Delorenzi M, Hegi ME, et al. Genome-wide DNA methylation detection by MethylCap-seq and Infinium HumanMethylation450 BeadChips: an independent large-scale comparison. Sci Rep. 2015;5:15375.

19. Esteller M, Herman JG. Cancer as an epigenetic disease: DNA methylation and chromatin alterations in human tumours. J Pathol. 2002;196:1-7.

20. Li S, Wen YH, Wei YJ, Wang YH, Liu HB. Aberrant DNA methylation and genome instability and mutation in cancer. Cancer Genet Epigenet. 2015;3:1-5.

21. Xia J, Han L, Zhao Z. Investigating the relationship of DNA methylation with mutation rate and allele frequency in the human genome. BMC Genomics. 2012;13(Suppl 8):S7.

22. Mugal CF, Ellegren $\mathrm{H}$. Substitution rate variation at human $\mathrm{CpG}$ sites correlates with non-CpG divergence, methylation level and GC content. Genome Biol. 2011;12:R58.

23. Holliday R. Grigg GW. DNA methylation and mutation. Mutat Res. 1993;285: 61-7.

24. Ehrlich M, Wang RYH. 5-Methylcytosine in eukaryotic DNA. Science. 1981; 212:1350-7.

25. Langmead B, Salzberg SL. Fast gapped-read alignment with bowtie 2. Nat Methods. 2012:9:357-9.

26. Chavez L, Lienhard M, Dietrich J. MEDIPS: (MeD)IP-seq data analysis. R package version 1.14.0. 2013.

27. Péterfia B, Kalmár A, Patai ÁV, Csabai I, Bodor A, Micsik T, Wichmann B, Egedi K, Hollósi P, Kovalszky I, et al. Construction of a multiplex mutation hot spot PCR panel: the first step towards colorectal cancer genotyping on the GS junior platform. J Cancer. 2017:8:162-73.

28. Galamb O, Wichmann B, Sipos F, Spisák S, Krenács T, Tóth K, Leiszter K, Kalmár A, Tulassay Z, Molnár B. Dysplasia-carcinoma transition specific transcripts in colonic biopsy samples. PLoS One. 2012;7:e48547.

29. Matsuyama T, Ishikawa T, Mogushi K, Yoshida T, lida S, Uetake H, Mizushima H, Tanaka H, Sugihara K. MUC12 mRNA expression is an independent marker of prognosis in stage II and stage III colorectal cancer. Int J Cancer. 2010;127:2292-9.

30. Hong Y, Ho KS, Eu KW, Cheah PY. A susceptibility gene set for early onset colorectal cancer that integrates diverse signaling pathways: implication for tumorigenesis. Clin Cancer Res. 2007;13:1107-14.

31. Hong Y, Downey T, Eu KW, Koh PK, Cheah PY. 'A metastasis-prone' signature for early-stage mismatch-repair proficient sporadic colorectal cancer patients and its implications for possible therapeutics. Clin Exp Metastasis. 2010:27:83-90.

32. Tang H, Guo Q, Zhang C, Zhu J, Yang H, Zou YL, Yan Y, Hong D, Sou T, Yan $X M$. Identification of an intermediate signature that marks the initial phases of the colorectal adenoma-carcinoma transition. Int J Mol Med. 2010;26: $631-41$

33. Sabates-Bellver J, Van der Flier LG, de Palo M, Cattaneo E, Maake C,

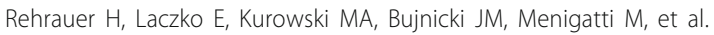
Transcriptome profile of human colorectal adenomas. Mol Cancer Res. 2007:5:1263-75.

34. Barták BK, Kalmár A, Bálint Péterfia B, Patai ÁV, Galamb O, Valcz G, Spisák S, Wichmann B, Nagy ZB, Tóth K, et al. Colorectal adenoma and cancer 
detection based on altered methylation pattern of SFRP1, SFRP2, SDC2 and PRIMA1 in plasma samples. Epigenetics. 2017. doi: https://doi.org/10.1080/ 15592294.2017.1356957. [Epub ahead of print]

35. Ogino S, Nosho K, Kirkner GJ, Kawasaki T, Chan AT, Schernhammer ES, Giovannucci EL, Fuchs CS. A cohort study of tumoral LINE-1 hypomethylation and prognosis in colon cancer. J Natl Cancer Inst. 2008;100:1734-8.

36. Mima K, Nowak JA, Qian ZR, Cao Y, Song M, Masugi Y, Shi Y, da Silva A, Gu M, Li W, et al. Tumor LINE-1 methylation level and colorectal cancer location in relation to patient survival. Oncotarget. 2016;7:55098-109.

37. Sunami E, de Maat M, Vu A, Turner RR, Hoon DS. LINE-1 hypomethylation during primary colon cancer progression. PLoS One. 2011;6:e18884.

38. Hollington P, Neufing P, Kalionis B, Waring P, Bentel J, Wattchow D, Tilley WD. Expression and localization of homeodomain proteins DLX4, HB9 and HB24 in malignant and benign human colorectal tissues. Anticancer Res. 2004;24:955-62.

39. Liu T, Chen J, Xiao S, Lei X. H2.0-like homeobox 1 acts as a tumor suppressor in hepatocellular carcinoma. Tumour Biol. 2016;37:6419-28.

40. Dai YC, Zhu XS, Nan QZ, Chen ZX, Xie JP, Fu YK, Lin YY, Lian QN, Sang QF, Zhan XJ. Identification of differential gene expressions in colorectal cancer and polyp by CDNA microarray. World J Gastroenterol. 2012;18:570-5.

41. Sepulveda JL, Gutierrez-Pajares JL, Luna A, Yao Y, Tobias JW, Thomas S, Woo Y, Giorgi F, Komissarova EV, Califano A, et al. High-definition CpG methylation of novel genes in gastric carcinogenesis identified by nextgeneration sequencing. Mod Pathol. 2016;29:182-93.

42. Chong Y, Mia-Jan K, Ryu H, Abdul-Ghafar J, Munkhdelger J, Lkhagvadorj S, Jung SY, Lee M, Ji SY, Choi E, et al. DNA methylation status of a distinctively different subset of genes is associated with each histologic Lauren classification subtype in early gastric carcinogenesis. Oncol Rep. 2014;31: 2535-44.

43. Pirini F, Noazin S, Jahuira-Arias MH, Rodriguez-Torres S, Friess L, Michailidi C, Cok J, Combe J, Vargas G, Prado W, et al. Early detection of gastric cancer using global, genome-wide and IRF4, ELMO1, CLIP4 and MSC DNA methylation in endoscopic biopsies. Oncotarget. 2017:8:38501-16.

44. Wang K, Liang Q, Li X, Tsoi H, Zhang J, Wang H, Go MY, Chiu PW, Ng EK, Sung $\mathrm{J}$, et al. MDGA2 is a novel tumour suppressor cooperating with DMAP1 in gastric cancer and is associated with disease outcome. Gut. 2016; 65:1619-31.

45. Matsusaka K, Kaneda A, Nagae G, Ushiku T, Kikuchi Y, Hino R, Uozaki H, Seto Y, Takada K, Aburatani H, et al. Classification of Epstein-Barr virus-positive gastric cancers by definition of DNA methylation epigenotypes. Cancer Res. 2011;71:7187-97.

46. Komatsu M, Sasaki H. DNA methylation is a key factor in understanding differentiation phenotype in esophageal squamous cell carcinoma. Epigenomics. 2014;6:567-9.

47. Tsao CM, Yan MD, Shih YL, Yu PN, Kuo CC, Lin WC, Li HJ, Lin YW. SOX1 functions as a tumor suppressor by antagonizing the WNT/ $\beta$-catenin signaling pathway in hepatocellular carcinoma. Hepatology. 2012;56:2277-87.

48. Silva AL, Dawson SN, Arends MJ, Guttula K, Hall N, Cameron EA, Huang TH, Brenton JD, Tavaré S, Bienz M, et al. Boosting Wnt activity during colorectal cancer progression through selective hypermethylation of Wnt signaling antagonists. BMC Cancer. 2014;14:891.

49. Farkas SA, Vymetalkova V, Vodickova L, Vodicka P, Nilsson TK. DNA methylation changes in genes frequently mutated in sporadic colorectal cancer and in the DNA repair and Wnt/B-catenin signaling pathway genes. Epigenomics. 2014;6:179-91.

50. Silva TD, Vidigal VM, Felipe AV, DE Lima JM, Neto RA, Saad SS, Forones NM. DNA methylation as an epigenetic biomarker in colorectal cancer. Oncol Lett. 2013;6:1687-92.

51. Gonzalo V, Lozano JJ, Muñoz J, Balaguer F, Pellisé M, Rodríguez de Miguel C, Andreu M, Jover R, Llor X, Giráldez MD, et al. Aberrant gene promoter methylation associated with sporadic multiple colorectal cancer. PLoS One. 2010;5:88777.

52. Harada T, Yamamoto E, Yamano HO, Nojima M, Maruyama R, Kumegawa K, Ashida M, Yoshikawa K, Kimura T, Harada E, et al. Analysis of DNA methylation in bowel lavage fluid for detection of colorectal cancer. Cancer Prev Res (Phila). 2014;7:1002-10.

53. Oh T, Kim N, Moon Y, Kim MS, Hoehn BD, Park CH, Kim TS, Kim NK, Chung $\mathrm{HC}$, An S. Genome-wide identification and validation of a novel methylation biomarker, SDC2, for blood-based detection of colorectal cancer. J Mol Diagn. 2013;15:498-507.
54. Mitchell SM, Ross JP, Drew HR, Ho T, Brown GS, Saunders NF, Duesing KR, Buckley MJ, Dunne R, Beetson I, et al. A panel of genes methylated with high frequency in colorectal cancer. BMC Cancer. 2014;14:54.

55. Hibi K, Goto T, Kitamura YH, Yokomizo K, Sakuraba K, Shirahata A, Mizukami H, Saito M, Ishibashi K, Kigawa G, et al. Methylation of TFPI2 gene is frequently detected in advanced well-differentiated colorectal cancer. Anticancer Res. 2010;30:1205-7.

56. Ashktorab H, Rahi H, Wansley D, Varma S, Shokrani B, Lee E, Daremipouran M, Laiyemo A, Goel A, Carethers JM, et al. Toward a comprehensive and systematic methylome signature in colorectal cancers. Epigenetics. 2013;8: 807-15.

57. Gan L, Chen S, Zhong J, Wang X, Lam EK, Liu X, Zhang J, Zhou T, Yu J, Si J, et al. ZIC1 is downregulated through promoter hypermethylation, and functions as a tumor suppressor gene in colorectal cancer. PLoS One. 2011; 6:e16916.

58. Moon JW, Lee SK, Lee JO, Kim N, Lee YW, Kim SJ, Kang HJ, Kim J, Kim HS, Park SH. Identification of novel hypermethylated genes and demethylating effect of vincristine in colorectal cancer. J Exp Clin Cancer Res. 2014;33:4.

59. Oster B, Thorsen K, Lamy P, Wojdacz TK, Hansen LL, Birkenkamp-Demtröder K, Sørensen KD, Laurberg S, Orntoft TF, Andersen CL. Identification and validation of highly frequent $\mathrm{CpG}$ island hypermethylation in colorectal adenomas and carcinomas. Int J Cancer. 2011;129:2855-66.

60. Lofton-Day C, Model F, Devos T, Tetzner R, Distler J, Schuster M, Song X, Lesche R, Liebenberg V, Ebert M, et al. DNA methylation biomarkers for blood-based colorectal cancer screening. Clin Chem. 2008:54:414-23.

61. Syed Sameer A, Shah ZA, Abdullah S, Chowdri NA, Siddiqi MA. Analysis of molecular aberrations of Wnt pathway gladiators in colorectal cancer in the Kashmiri population. Hum Genomics. 2011;5:441-52.

62. Judson H, Stewart A, Leslie A, Pratt NR, Baty DU, Steele RJ, Carey FA. Relationship between point gene mutation, chromosomal abnormality, and tumour suppressor gene methylation status in colorectal adenomas. J Pathol. 2006;210:344-50.

63. Schmutte C, Yang AS, Nguyen TT, Beart RW, Jones PA. Mechanisms for the involvement of DNA methylation in colon carcinogenesis. Cancer Res. 1996; $56: 2375-81$.

64. Tubbs A, Nussenzweig A. Endogenous DNA damage as a source of genomic instability in Cancer. Cell. 2017;168:644-56.

65. Supek F, Lehner B, Hajkova P, Warnecke T. Hydroxymethylated cytosines are associated with elevated C to $\mathrm{G}$ transversion rates. PLoS Genet. 2014;10: e1004585.

66. Poulos RC, Olivier J, Wong JWH. The interaction between cytosine methylation and processes of DNA replication and repair shape the mutational landscape of cancer genomes. Nucleic Acids Res. 2017;45:7786-95.

67. Herrero AB, Rojas EA, Misiewicz-Krzeminska I, Krzeminski P, Gutiérrez NC. Molecular mechanisms of p53 deregulation in cancer: an overview in multiple myeloma. Int J Mol Sci. 2016;17:2003.

68. Macedo GS, Vieira IA, Vianna FSL, Alemar B, Giacomazzi J, Brandalize APC, Caleffi M, Volc SM. de Campos reis Galvão H, Palmero El, et al. p53 signaling pathway polymorphisms, cancer risk and tumor phenotype in TP53 R337Hmutation carriers. Familial Cancer. 2017; https://doi.org/10.1007/ s10689-017-0028-4. [Epub ahead of print]

69. Choi MR, Gwak M, Yoo NJ, Lee SH. Regional bias of intratumoral genetic heterogeneity of apoptosis-related genes BAX, APAF1, and FLASH in colon cancers with high microsatellite instability. Dig Dis Sci. 2015;60:1674-9.

70. Pearlman R, Frankel WL, Swanson B, Zhao W, Yilmaz A, Miller K, Bacher J, Bigley C, Nelsen L, Goodfellow PJ, et al. Prevalence and spectrum of germline cancer susceptibility gene mutations among patients with earlyonset colorectal cancer. JAMA Oncol. 2017;3:464-71.

71. Devaney JM, Wang S, Funda S, Long J, Taghipour DJ, Tbaishat R, FurbertHarris P, Ittmann M, Kwabi-Addo B. Identification of novel DNA-methylated genes that correlate with human prostate cancer and high-grade prostatic intraepithelial neoplasia. Prostate Cancer Prostatic Dis. 2013;16:292-300.

72. Gil J, Ramsey D, Szmida E, Leszczynski P, Pawlowski P, Bebenek M, Sasiadek $M M$. The BAX gene as a candidate for negative autophagy-related genes regulator on mRNA levels in colorectal cancer. Med Oncol. 2017;34:16.

73. Bednarek K, Kiwerska K, Szaumkessel M, Bodnar M, Kostrzewska-Poczekaj M, Marszalek A, Janiszewska J, Bartochowska A, Jackowska J, Wierzbicka M, et al. Recurrent CDK1 overexpression in laryngeal squamous cell carcinoma. Tumour Biol. 2016;37:11115-26.

74. Ogino S, Nosho K, Shima K, Baba Y, Irahara N, Kirkner GJ, Hazra A, De Vivo I, Giovannucci EL, Meyerhardt JA, et al. p21 expression in colon cancer and 
modifying effects of patient age and body mass index on prognosis. Cancer Epidemiol Biomark Prev. 2009;18:2513-21

75. Coppedè F, Migheli F, Lopomo A, Failli A, Legitimo A, Consolini R, Fontanini G, Sensi E, Servadio A, Seccia M, et al. Gene promoter methylation in colorectal cancer and healthy adjacent mucosa specimens: correlation with physiological and pathological characteristics, and with biomarkers of onecarbon metabolism. Epigenetics. 2014;9:621-33.

76. Psofaki V, Kalogera C, Tzambouras N, Stephanou D, Tsianos E, Seferiadis K, Kolios G. Promoter methylation status of hMLH1, MGMT, and CDKN2A/p16 in colorectal adenomas. World J Gastroenterol. 2010;16:3553-60.

77. Payne CM, Holubec H, Bernstein C, Bernstein H, Dvorak K, Green SB, Wilson M, Dall'Agnol M, Dvorakova B, Warneke J, et al. Crypt-restricted loss and decreased protein expression of cytochrome $C$ oxidase subunit I as potential hypothesis-driven biomarkers of colon cancer risk. Cancer Epidemiol Biomark Prev. 2005;14:2066-75.

78. Han C, Zhao R, Liu X, Srivastava A, Gong L, Mao H, Qu M, Zhao W, Yu J, Wang QE. DDB2 suppresses tumorigenicity by limiting the cancer stem cell population in ovarian cancer. Mol Cancer Res. 2014;12:784-94.

79. Roy N, Bommi PV, Bhat UG, Bhattacharjee S, Elangovan I, Li J, Patra KC, Kopanja D, Blunier A, Benya R, et al. DDB2 suppresses epithelial-tomesenchymal transition in colon cancer. Cancer Res. 2013;73:3771-82.

80. Short B. GTSE1 leads cancer cells into CIN. J Cell Biol. 2016:215:593.

81. Tian T, Zhang E, Fei F, Li X, Guo X, Liu B, Li J, Chen Z, Xing J. Up-regulation of GTSE1 lacks a relationship with clinical data in lung cancer. Asian Pac J Cancer Prev. 2011;12:2039-43.

82. Jin X, Liu X, Li X, Guan Y. Integrated analysis of DNA methylation and mRNA expression profiles data to identify key genes in lung adenocarcinoma. Biomed Res Int. 2016;2016:4369431.

83. Ye P, Qu CF, Hu XL. Impact of IGF-1, IGF-1R, and IGFBP-3 promoter methylation on the risk and prognosis of esophageal carcinoma. Tumour Biol. 2016;37:6893-904.

84. Keku TO, Sandler RS, Simmons JG, Galanko J, Woosley JT, Proffitt M, Omofoye O, McDoom M, Lund PK. Local IGFBP-3 mRNA expression, apoptosis and risk of colorectal adenomas. BMC Cancer. 2008;8:143.

85. Wei JL, Fu ZX, Fang M, Guo JB, Zhao QN, Lu WD, Zhou QY. Decreased expression of sestrin 2 predicts unfavorable outcome in colorectal cancer. Oncol Rep. 2015;33:1349-57.

86. Xu H, Sun H, Zhang H, Liu J, Fan F, Li Y, Ning X, Sun Y, Dai S, Liu B, et al. An shRNA based genetic screen identified Sesn2 as a potential tumor suppressor in lung cancer via suppression of Akt-mTOR-p70S6K signaling. PLoS One. 2015;10:e124033.

87. Ro SH, Xue X, Ramakrishnan SK, Cho CS, Namkoong S, Jang I, Semple IA, Ho A, Park HW, Shah YM, et al. Tumor suppressive role of sestrin2 during colitis and colon carcinogenesis. elife. 2016;5:e12204.

88. Choi SH, Hong HK, Cho YB, Lee WY, Yoo HY. Identification of Sestrin3 involved in the in vitro resistance of colorectal cancer cells to irinotecan. PLoS One. 2015;10:e126830.

\section{Ready to submit your research? Choose BMC and benefit from:}

- fast, convenient online submission

- thorough peer review by experienced researchers in your field

- rapid publication on acceptance

- support for research data, including large and complex data types

- gold Open Access which fosters wider collaboration and increased citations - maximum visibility for your research: over $100 \mathrm{M}$ website views per year

At BMC, research is always in progress.

Learn more biomedcentral.com/submissions 